\title{
Relations between the yield of bean (Phaseolus vulgaris L.) and chemical attributes of an Acrustox under no-tillage
}

\author{
R. Montanari ${ }^{1}$, M. de Passos e Carvalho ${ }^{1}$, C.A. da Silva Junior ${ }^{2 *}$, A. Rodrigues Corrêa ${ }^{3}$, F. C. Dalchiavon ${ }^{1}$, \\ A. Paz González ${ }^{4}$
}

${ }^{1}$ College of Engineering (UNESP/FEIS) Ilha Solteira, SP, Brazil. ${ }^{2}$ State University of Maringá (UEM), Maringá, PR, Brazil. ${ }^{3}$ State University of Mato Grosso do Sul (UEMS), Aquidauana, MS, Brazil. ${ }^{4}$ University of Coruña (UDC), Faculty of Sciences, Coruña, Spain. *Corresponding author: carlos-junior89@hotmail.com

\begin{abstract}
In crop year 2006/07, in Selvíria, MS, Brazil, were analyzed the productivity of beans because of the chemical attributes of an Acrustox cultivated under conditions of high technological level of management by no-tillage irrigated with pivot central. The objective was to select, among the attributes studied soil, the one with the best representation to explain the variability of agricultural productivity. Geostatistical grid was installed to collect data from soil and plant, with 117 sampling points in an area of 2,025 $\mathrm{m}^{2}$ and homogeneous slope of $0.055 \mathrm{~m} \mathrm{~m}^{-1}$. From the standpoint of linear and spatial bean yield was respectively explained in terms of $\mathrm{P}$ and soil $\mathrm{pH}$. So much for the values of phosphorus $(\mathrm{P})$ in the intermediate layer and subsurface between $24-26 \mathrm{mg} \mathrm{dm}^{-3}$, as well as for Hydrogen $(\mathrm{pH})$ in the surface layer between 5.0 to 5.4 , resulted in sites with the most high yield $\left(2,160-2,665 \mathrm{~kg} \mathrm{ha}^{-1}\right)$.
\end{abstract}

Keywords: Soil management, no-tillage system, agricultural sustainability, Phaseolus vulgaris L.

\section{Introduction}

In Brazil, the culture of bean (Phaseolus vulgaris L.), constitutes one of the most major farms, not only for the area of cultivation as well as by value of production. It is a vegetable essential in basic power of the national population, since it is the main source of protein and iron (Buratto et al., 2009). Regarding the arrangement of the root system in the soil, it resembles fasciculate, once the primary root is not a typical axial, and mostly lie within the first $0.20 \mathrm{~m}$ deep, with $62-87 \%$ of the first $0.10 \mathrm{~m}$ (Montanari et al., 2010). As a result, the plant operates fundamentally their surface layer, being therefore very sensitive to the lack of moisture, to compaction and soil fertility (Vieira et al., 2006). The bean is one of the main crops planted in the Midwest, Northeast and Southeast of Brazil, being that in crop year 2009/2010, the acreage for the "third season" in these areas was approximately 560 thousand hectares, with an average productivity of $1,909 \mathrm{~kg} \mathrm{ha}^{-1}$ (Conab, 2012). 
In some areas of the mid-western region of Brazil soil has gone through some physical and chemical degradation problems, being that: a) is deficient in phosphorus $(\mathrm{P})$ due to the acidic $\mathrm{pH}$ and the presence of high proportions of oxides of $\mathrm{Fe}$ and $\mathrm{Al}$ in the clay fraction, which makes phosphate fixation, thereby decreasing the availability of $\mathrm{P}$ applied, in addition to the natural process of formation which features the labile and no-labile P; and b) as a result of its intensive usage has also suffered heavily with erosion, loss of fertility, organic matter content reduction and mainly with the compressed layers formation (Novais and Smyth, 1999; Ramos et al., 2010). This compression generates substantial change their structure, triggering the reorganization of the particles and their aggregates, which may limit the absorption of nutrients, the infiltration and redistribution of water, gas exchange and growth of root system, resulting in decreased crop yields (Roque et al., 2008), in addition to, the $\mathrm{P}$ deficiency is considered to be limiting for plant productivity in tropical regions (Fageria and Baligar, 1996).

Under the conditions of climate and soils of the Cerrado (Brazilian Savanna), the no-tillage system is a successful management practice (Corrêa and Sharma, 2004; Carneiro et al., 2009; Carvalho et al., 2011a), however requires more information about species for coverage, which should have a good biomass production and be persistent enough for adequate physical protection of the soil and nutrient availability, during periods in which there is excess or shortage of water, resulting in benefits for the later culture.

The geostatistical analysis of soil variability can indicate management alternatives, not only to reduce the effects of variability of soil attributes on agricultural production, but also to increase their response to the various cultural practices employed (Trangmar et al., 1985; Carvalho et al., 2011b; Carvalho et al., 2012). Thus, the collection of spatial values of a given attribute may reveal wide variations because the soil is a product of the action of various factors training varies greatly in its three dimensions, especially the surface (Roque et al., 2008; Montanari et al., 2012). These procedures for determining whether or not an attribute presents spatial structure and, once you know the model of spatial dependence, it is possible to map the area studied. Thus, the zones are established specific management that are critical to the application of inputs with varying rates, conditions necessary for precision agriculture (Coelho, 2003).

With the emergence of the precision agriculture, lately in Brazil the study of geostatistics in respect of soil attributes and the productivity of the bean has been increasingly intensifying (Freddi et al., 2005; Santos et al., 2005; Carvalho et al., 2006; Kitamura et al., 2007; Roque et al., 2008; Martins et al., 2009).

Given the above, having the bean culture established in Selvíria, Mato Grosso do Sul State, Brazil, under conditions of high technological level of management, the objective of this research was to search among the studied chemical attributes of soil under no-tillage, those that best present to explain, linear and spatially, grain productivity variability of beans.

\section{Material and Methods}

\subsection{Description of research area}

The experiment was conducted at Farm Teaching, research and extension of the Faculty of Engineering of Ilha Solteira (FEIS/UNESP), in the municipality of Selvíria (MS, Brazil), at Lat. $20^{\circ} 22^{\prime}$ S and Long. $51^{\circ} 22^{\prime} \mathrm{W}$, with an annual average rainfall is $1,300 \mathrm{~mm}$, while their average temperature is $74.6^{\circ} \mathrm{F}$. The climate is type Aw, according to Köppen-Geiger, characterized as tropical wet with a rainy season in the summer and dry in winter. The soil in which the grid was installed is an Acrustox dystroferric typical very clayey (Soil Survey Staff, 1998). Their granulometry, parsed from the surface up to $0.30 \mathrm{~m}$, is $620 \mathrm{~g} \mathrm{~kg}^{-1}$ clay, $100 \mathrm{~g} \mathrm{~kg}^{-1}$ of silt, $60 \mathrm{~g} \mathrm{~kg}^{-1}$ of coarse sand and $220 \mathrm{~g} \mathrm{~kg}^{-1}$ of fine sand, which gives very clayey texture. This has been 
grown for at least twenty years with the succession of crops of maize and beans sown in summer and winter respectively. In the years 1998 and 2003, in two seasons, the soil was prepared with the plow of moldboard. However, on the other, by tillage system irrigated under center pivot.

\section{2. sampling and measurements}

The test plant searched was the bean (Phaseolus vulgaris L.), sown in 5/6/2006 after desiccation weed with the herbicide glyphosate, at a dose of $1.8 \mathrm{~kg} \mathrm{ha}^{-1}$ of the active ingredient. The cultivar sown was the Pérola, whose cultivation was conducted in accordance with the instructions for the main agricultural crops of the State of São Paulo, Brazil (Fahl et al., 1998). Thus, the spacing was $0.45 \mathrm{~m}$, with a final density of 16 plants per line of sowing. The $\mathrm{x}$ and $\mathrm{y}$ directions were established in the Cartesian Coordinate System, established between two agricultural terraces, where was sown the culture studied. It was the common optical level, effecting the global staking after sowing in experimental grid, i.e., in June 2006. This grid was constituted of 9 transects of $40 \times 40 \mathrm{~m}$ in length with an area of $2,025 \mathrm{~m}^{2}$. The transects were spaced out of $5.00 \mathrm{~m}$, with sample points in the form of $5.00 \mathrm{~m} \times 5.00 \mathrm{~m}$, containing 81 of them. However, were added, within the large grid points with spaces smaller than those mentioned, with $1.67 \mathrm{~m}$ between them, in order to elaborate the study of spatial dependence. As in this case were 36 , the total sample points of the grid were 117.

The attributes of soil were studied: a) phosphorus (P), b) organic matter $(\mathrm{OM})$, and c) potential Hydrogen $(\mathrm{pH})$, collected in 6/18/2006 in three depths: $1^{\text {st }}$ ) $\left.0-0.10 \mathrm{~m}, 2^{\text {nd }}\right) 0.10-0.20 \mathrm{~m}$ and $\left.3^{\text {th }}\right) 0.20-0.30 \mathrm{~m}$. Was evaluated the productivity of grain of bean (PGB) held in $8 / 14 / 2006$. Collected four lines of sowing $(1.80 \mathrm{~m})$, so there are always two on either side of the sample point. As the length in the direction of the lines also amounted to $1.80 \mathrm{~m}$, the area harvested was $3.24 \mathrm{~m}^{2}$. Therefore, the list of 10 attributes searched was the following: PGB, OM1, OM2, OM3, P1, P2, P3, pH1, $\mathrm{pH} 2$ and $\mathrm{pH} 3$.
The soil available phosphorus content $(\mathrm{P})$ was determined by extraction method with ion exchange resin, given as $\mathrm{mg} \mathrm{dm}^{-3}$ (Raij et al., 1987), the $\mathrm{pH}$ was determined potentiometrically in $0,01 \mathrm{M} \mathrm{CaCl} 2$ solution, while the organic carbon was by wet combustion method, by colorimetric, resulting in soil organic matter content (OM) by the following expression (Raij et al., 1987):

$\mathrm{OM}=\mathrm{C} \cdot 17.24$

where: $\mathrm{OM}$ is the quantity of organic matter ( $\mathrm{g} \mathrm{dm}$ ${ }^{3}$ ) and $\mathrm{C}$ is the carbon content $\left(\mathrm{g} \mathrm{dm}^{-3}\right)$. All analyses were performed in the laboratory of soil physics and Chemistry Engineering College of Calcutta - UNESP.

\subsection{Data analysis}

For the attributes studied, there was the classical descriptive analysis, with the aid of SAS statistical software (Schlotzhaver and Littell, 1997), which were calculated the mean, median, minimum and maximum values, standard deviation, coefficient of variation, kurtosis, asymmetry and frequency distribution. Was then performed to identify outliers, making the substitution by the average of the values contained in the grid surrounding geostatistics. To perform the test of the hypothesis of normality, or lognormality, was used the Shapiro \& Wilk 5\%. Was assembled the correlation matrix, aiming to make the linear regressions for the combinations, two by two, among the attributes studied. Therefore, was selected those of higher linear correlation and thus could exhibit cross semivariogram and the resulting cokriging. For each attribute, was to study the spatial dependence using the semivariogram simple calculation based on the assumptions of stationarity of the intrinsic hypothesis, using the Gamma Design Software package (GS+, 2004)

$\mathrm{SDE}=[\mathrm{C} /(\mathrm{C}+\mathrm{Co})] .100$ 
where: SDE is the appraiser spatial dependence; C, the structural variance; and $\mathrm{C}+\mathrm{Co}$, the landing. The interpretation proposed for the SDE was as follows: $25 \% \leq \mathrm{SDE}$ indicated spatial weakly dependent variable; $25 \%<\mathrm{SDE} \leq 75 \%$ indicated spatial variable moderately dependent; and $\mathrm{SDE}>75 \%$ indicated spatial strongly dependent variable. However, crossvalidation is a tool used to evaluate alternative models of single and cross semivariograms, which will affect subsequently respectively kriging and cokriging. In its analysis, each point contained within the spatial domain is removed individually, with their estimated value as if it did not exist. Thus, one can construct a graph of observed versus estimated values for all points. The correlation coefficient (r) between such values reflects the efficiency of setting, by the technique given the sum of squares of deviations, representing the linear regression equation in question.

With a perfect fit would present the regression coefficient equal to 1 and the line of best fit coincide with the perfect model, i.e., with the linear coefficient equal to zero and the angular equal to $1(\mathrm{GS}+, 2004)$. Thus, working on getting the optimal number of neighbors, were obtained by interpolation maps of kriging and co-kriging for analysis of spatial dependence and interdependence between attributes.

\section{Results and Discussion}

In table 1 , are displayed the descriptive analysis of some chemical attributes studied in no-tillage system, where the productivity of grain (PGB) presented high variability, representing a $21 \%$ variation coefficient. However, this data were similar to those of Freddi et al. (2005), Martins (2007) and Kitamura et al. (2007) when investigated an Acrustox dystroferric under no-tillage in regular knitting 135 points, which were also high variability of $24 \%$ for the grain productivity of beans, but disagrees with of Megda et al. (2008), where she earned average variability $(19 \%)$ to the bean grain productivity.
The organic matter $(\mathrm{OM})$ in the depths of $0-0.10$, $0.10-0.20$ and $0.20-0.30 \mathrm{~m}$ showed high variability average, 14,19 and $21 \%$ respectively (Table 1 ). These data corroborate with those of Bezerra (2008), where he studied under no-tillage, a Typic Acrustox with 125 sample points, obtained high variability with 26 and $23 \%$ values in the depths $0-0.10$ and $0.10-0.20$ $\mathrm{m}$, respectively.

At all depths to the content of phosphorus (P), showed very high variability (Table 1 ), with variations between 32 to $62 \%$, so these data agree with those of Souza et al. (1998), which was 31 to $61 \%$ at depths 0-0.05 and 0.05-0.20 m, respectively, who studied an Ultisol distrophic in minimum cultivation system with a 40 grid points; and those of Bezerra (2008) where he worked in a Typic Acrustox under no-tillage in a grid of 125 points, which he obtained in the depths of $0-0.10$ and $0.10-0.20 \mathrm{~m}$ a $58-52 \%$ variability.

In relation to the potential hydrogen $(\mathrm{pH})$, low variability was obtained in three layers of soil, with coefficients of variation between $4-8 \%$, so these data are similar to those achieved by Freddi (2003) and Bezerra (2008), when they found a variance between $4-7 \%$, studying in an Acrustox dystroferric and distrophic under no-tillage, respectively (Table 1).

When a statistical variable has normal frequency distribution to measure of central tendency most suitable to represent it to be average. In contrast, the median, or the geometric mean, if lognormal type (Montanari, 2010). Thus, the tendency to represent the attributes $\mathrm{PGB}, \mathrm{OM} 3, \mathrm{pH} 1, \mathrm{pH} 2$ and $\mathrm{pH} 3$ shall be the average, because they had the frequency distribution of the normal type, with positive, asymmetry coefficients between 0.020 and 0.347 . Already the negative kurtosis coefficients were between -0.680 and -0.316 . However, all were significant at $5 \%$ probability by normality test of Shapiro and Wilk, since such a likelihood ranged from 0.055 and 0.850 (Table 1). Though, the normal frequency distribution obtained for such attributes, as the magnitudes of the coefficients of skewness and kurtosis were in general 
agreement with observed data by Souza et al., 1998, Megda et al. (2008) and Montanari et al. (2008). The attributes $\mathrm{OM} 1$ and $\mathrm{P} 2$ show frequency distribution of the type tending to lognormal, P1 and P3 had frequency distribution lognormal type, whereas the OM2 type undetermined. Based on geostatistics studies, that evaluate the correlations between the average productivity of beans and soil attributes, the average yield obtained $\left(2,201 \mathrm{~kg} \mathrm{ha}^{-1}\right)$ (Table 1) was $15.2 \%$ lower than those of Kitamura et al. (2007) and Martins et al. (2009), which were 2,594 $\mathrm{kg} \mathrm{ha}{ }^{-1}$. However, they were $21.7 \%$ and $31.1 \%$ bigger than the Roque et al. (2008) and Carvalho et al. (2006), respectively, which were 1,809 and $1,679 \mathrm{~kg} \mathrm{ha}^{-1}$.

Table 1. Descriptive analysis of the productivity of beans and some chemical properties of a Typic Acrustox under notillage in Selvíria, MS, Brazil.

\begin{tabular}{|c|c|c|c|c|c|c|c|c|c|c|}
\hline \multirow{3}{*}{ Attributes $^{(a)}$} & \multicolumn{10}{|c|}{ Measures Descriptive Statistics } \\
\hline & \multirow[b]{2}{*}{ Mean } & \multirow[b]{2}{*}{ Median } & \multicolumn{2}{|c|}{ Value } & \multirow{2}{*}{$\begin{array}{l}\text { Standar } \\
\text { d } \\
\text { Deviatio } \\
\text { n }\end{array}$} & \multicolumn{3}{|c|}{ Coefficient } & \multicolumn{2}{|c|}{$\begin{array}{c}\text { Probability } \\
\text { test }^{(B)}\end{array}$} \\
\hline & & & minimum & maximum & & $\begin{array}{c}\text { variation } \\
(\%)\end{array}$ & kurtosis & Asymmetry & $\operatorname{Pr}<w$ & FD \\
\hline \multicolumn{11}{|c|}{ Attribute plant } \\
\hline PGB (kg ha $\left.{ }^{-1}\right)$ & 2200.9 & 2206.9 & 1225.2 & 3390.0 & 464.7 & 21.1 & -0.625 & 0.020 & $0.217^{\mathrm{ns}}$ & NO \\
\hline & \multicolumn{10}{|c|}{ Chemical soil attribrutes } \\
\hline OM1 $\left(\mathrm{g} \mathrm{dm}^{-3}\right)$ & 18.3 & 18.1 & 13.5 & 25.4 & 2.671 & 14.6 & -0.633 & 0.090 & $0.017^{*}$ & TL \\
\hline OM2 $\left(\mathrm{g} \mathrm{dm}^{-3}\right)$ & 17.7 & 16.9 & 9.1 & 24.2 & 3.352 & 18.9 & - & - & - & IN \\
\hline OM3 $\left(\mathrm{g} \mathrm{dm}^{-3}\right)$ & 14.8 & 14.6 & 6.9 & 22.9 & 3.100 & 20.8 & -0.316 & 0.094 & $0.202^{\text {ns }}$ & NO \\
\hline P1 (mg dm $\left.{ }^{-3}\right)$ & 20.0 & 20.0 & 7.0 & 40.0 & 6.557 & 32.7 & -0.160 & 0.017 & $0.092^{\mathrm{ns}}$ & $\mathrm{LN}$ \\
\hline P2 $\left(\mathrm{mg} \mathrm{dm}^{-3}\right)$ & 17.0 & 16.0 & 4.0 & 51.0 & 8.928 & 52.7 & 0.115 & -0.052 & $0.403^{\text {ns }}$ & TL \\
\hline P3 $\left(\mathrm{mg} \mathrm{dm}^{-3}\right)$ & 11.6 & 10.0 & 2.0 & 38.0 & 7.220 & 62.4 & 0.229 & -0.043 & $0.083^{\text {ns }}$ & LN \\
\hline $\mathrm{pH} 1\left(\mathrm{CaCl}_{2}\right)$ & 4.9 & 4.9 & 4.2 & 5.7 & 0.347 & 7.0 & -0.680 & 0.347 & $0.174^{\mathrm{ns}}$ & NO \\
\hline $\mathrm{pH} 2\left(\mathrm{CaCl}_{2}\right)$ & 5.0 & 5.0 & 4.3 & 5.7 & 0.331 & 6.6 & -0.488 & 0.051 & $0.595^{\mathrm{ns}}$ & NO \\
\hline $\mathrm{pH} 3\left(\mathrm{CaCl}_{2}\right)$ & 5.0 & 5.0 & 4.3 & 5.8 & 0.338 & 6.7 & -0.383 & 0.036 & $0.840^{\mathrm{ns}}$ & NO \\
\hline
\end{tabular}

(a) $\mathrm{PGB}=$ productivity of grain of bean; $\mathrm{OM}, \mathrm{P}, \mathrm{pH}$, going 1 and 3, are respectively the content of organic matter, phosphorus and hydrogen potential, collected in layers of soil from $0.00-0.10,0.10-.020$ and $0.20-0.30 \mathrm{~m}$; ${ }^{\text {(b) }} \mathrm{FD}=$ frequency distribution, and NO, LN, TL and IN respectively type normal, lognormal, tending to lognormal and indeterminate. *Significant at the $5 \%$; ${ }^{\text {ns }}$ not significant. 
The Table 2 shows the correlation matrix between the simple linear attribute bean (PGB) and soil chemical properties (organic matter, $\mathrm{pH}$ and $\mathrm{P}$ ) for no-tillage. The correlation between the attributes of the plant with the soil (Table 2) showed a negative correlation for pairs 1) PGB x OM1 $(r=-0.031), 2)$ PGB $\times \mathrm{P} 1(\mathrm{r}=$ $-0.116), 3) \mathrm{PGB} \times \mathrm{pH} 2(\mathrm{r}=-0.050)$ and 4$) \mathrm{PGB} \times \mathrm{pH} 3$ $(\mathrm{r}=-0.022)$. Already the pairs 1) OM1 x OM2 $(\mathrm{r}=$ $\left.\left.0.657^{* *}\right), 2\right)$ OM1 x OM3 (r $\left.\left.=0.264 * *\right), 3\right)$ OM1 x P2 $\left.\left.\left(\mathrm{r}=0.327^{* *}\right), 4\right) \mathrm{OM} 1 \mathrm{x} \mathrm{pH} 1\left(\mathrm{r}=0.507^{* *}\right), 5\right) \mathrm{OM} 1 \mathrm{x}$ $\left.\left.\mathrm{pH} 2\left(0.467^{* *}\right), 6\right) \mathrm{OM} 1 \times \mathrm{pH} 3\left(\mathrm{r}=0.369^{* *}\right), 7\right) \mathrm{OM} 2$ x OM3 $\left.\left(\mathrm{r}=0.533^{* *}\right), 8\right)$ OM2 x P2 $\left.(\mathrm{r}=0.392 * *), 9\right)$
$\mathrm{OM} 2 \times \mathrm{P} 3(\mathrm{r}=0.274 * *), 10) \mathrm{OM} 2 \times \mathrm{pH} 1(\mathrm{r}=0.496 * *)$, 11) $\mathrm{OM} 2 \times \mathrm{pH} 2(\mathrm{r}=0.579 * *), 12) \mathrm{OM} 2 \times \mathrm{pH} 3(\mathrm{r}=$ $\left.\left.0.517^{* *}\right), 13\right)$ OM3 x P2 (r $\left.\left.=0.286^{* *}\right), 14\right)$ OM3 x P3 $\left.(\mathrm{r}=0.412 * *), 15) \mathrm{OM} 3 \times \mathrm{pH} 2\left(\mathrm{r}=0.268^{* *}\right), 16\right) \mathrm{OM} 3$ $\left.\mathrm{x} \mathrm{pH3}\left(\mathrm{r}=0.242^{* *}\right), 17\right) \mathrm{P} 1$ x P2 $\left.(\mathrm{r}=0.324 * *), 18\right) \mathrm{P} 1$ x P3 $\left(\mathrm{r}=0.259^{* *}\right)$, 19) P1 x pH1 $\left.\left(\mathrm{r}=0.295^{* *}\right), 20\right)$ $\mathrm{P} 1 \times \mathrm{pH} 2\left(\mathrm{r}=0.272^{* *}\right)$, 21) $\mathrm{P} 1 \times \mathrm{pH} 3\left(\mathrm{r}=0.244^{* *}\right)$, 22) $\mathrm{P} 2 \times \mathrm{P} 3\left(\mathrm{r}=0.410^{* *}\right)$, 23) $\mathrm{P} 2 \mathrm{x} \mathrm{pH} 1\left(\mathrm{r}=0.258^{* *}\right)$, 24) $\mathrm{P} 2 \times \mathrm{pH} 2\left(\mathrm{r}=0.194^{*}\right)$, 25) $\mathrm{P} 3 \times \mathrm{pH} 1\left(\mathrm{r}=0.205^{*}\right)$, 26) $\left.\mathrm{pH} 1 \times \mathrm{pH} 2\left(\mathrm{r}=0.857^{* *}\right), 27\right) \mathrm{pH} 1 \times \mathrm{pH} 3(\mathrm{r}=$ $\left.0.740^{* *}\right)$ and 28) $\mathrm{pH} 2 \times \mathrm{pH} 2\left(\mathrm{r}=0.872^{* *}\right)$, have direct significance.

Table 2. Matrix of simple linear correlation between yield of beans (PGB) and some chemical attributes of a Typic Acrustox under no-tillage in Selvíria, MS, Brazil.

\begin{tabular}{|c|c|c|c|c|c|c|c|c|c|}
\hline \multirow{2}{*}{ Attributes $^{(a)}$} & \multicolumn{9}{|c|}{ Correlation coefficient $^{(b)}$} \\
\hline & PGB & OM1 & OM2 & OM3 & P1 & P2 & P3 & pH1 & $\mathrm{pH} 2$ \\
\hline OM1 & $-0.031^{\mathrm{ns}}$ & - & - & - & - & - & - & - & - \\
\hline OM2 & 0.037 & $0.657^{* *}$ & - & - & - & - & - & - & - \\
\hline OM3 & 0.006 & $0.264^{* *}$ & $0.533^{* *}$ & - & - & - & - & - & - \\
\hline P1 & -0.116 & 0.164 & 0.158 & 0.151 & - & - & - & - & - \\
\hline P2 & 0.103 & $0.327^{* *}$ & $0.392^{* *}$ & $0.286^{* *}$ & $0.324^{* *}$ & - & - & - & - \\
\hline P3 & 0.062 & 0.114 & $0.274^{* *}$ & $0.412^{* *}$ & $0.259^{* *}$ & $0.410^{* *}$ & - & - & - \\
\hline pH1 & 0.069 & $0.507^{* *}$ & $0.496^{* *}$ & 0.164 & $0.295^{* *}$ & $0.258^{* *}$ & $0.205^{*}$ & - & - \\
\hline pH2 & -0.050 & $0.467^{* *}$ & $0.579^{* *}$ & $0.268^{* *}$ & $0.272^{* *}$ & $0.194^{*}$ & 0.156 & $0.857^{* *}$ & - \\
\hline pH3 & -0.022 & $0.369^{* *}$ & $0.517^{* *}$ & $0.242^{* *}$ & $0.244^{* *}$ & 0.133 & 0.166 & $0.740^{* *}$ & $0.872^{* *}$ \\
\hline
\end{tabular}

(a) $\mathrm{PGB}=$ productivity of grain of bean; $\mathrm{OM}, \mathrm{P}, \mathrm{pH}$, going 1 and 3, are respectively the content of organic matter, phosphorus and hydrogen potential, collected in layers of soil from $0.00-0.10,0.10-.020$ and $0.20-0.30 \mathrm{~m}$; ${ }^{\text {(b) }}{ }^{*}$ Significant at the $5 \%$, ${ }^{*}$ Significant at the $1 \%$. ${ }^{\mathrm{ns}}$ not significant. 
In Table 3 are presented the parameters of simple semivariograms adjusted for productivity of beans and some chemical attributes of an Acrustox dystroferric, Selvíria (MS, Brazil) under notillage. Already in Figures 1 and 2 were presented their respective semivariograms. With regard to the performance of semivariograms (Table 2), the relationship of decreasing them, analyzed by the greatness of the coefficient of determination ( $\mathrm{r} 2)$, was as follows: 1) OM1 (0.997), 2) P1 (0.980), 3) $\mathrm{pH} 3(0.976), 4) \mathrm{P} 3(0.968), 5) \mathrm{pH} 2$ (0.936), 6) OM3 (0.920), 7) OM2 and $\mathrm{P} 2(0.912), 8) \mathrm{pH} 1$ (0.851) and 9) PGB (0.766). So, for the first three, which had high coefficients of determination, the following was observed. For the first (OM1), its value of $\mathrm{r} 2$ (0.997), which indicated that the bestfit attribute semivariographic, disagreeing that observed by Bezerra (2008), studying a cultivated with maize Acrustox, seeded on irrigated pastures, spatial variability found for OM1. For the second (P1, Table 2), the $\mathrm{r}^{2}$ value (0.980), which indicated that the second best-fit attribute semivariographic, disagreed with the results found by Manzione (2002), Weirich Neto et al. (2005) who worked respectively with Oxisol udic and ustic that pure nugget effect have been detected for phosphorus.

Still on Table 3, the ratio reaches down was as follows: 1) $\mathrm{pH} 3(23.2 \mathrm{~m})$; 2) OM2 (22.3 m); 3) pH1 and pH2 (21.1 m); 4) OM1 (19.2 m); 5) OM3 (15.5 m); 6) P2 (14.4 m); 7) P3 (11.1 m); 8) PGB $(10.7 \mathrm{~m})$; and 9) P1 $(8.8 \mathrm{~m})$. Therefore, under the conditions of this study, as well as to assist future research, in which the same attributes are involved, reaches values use in geostatistical packages, which will feed the computational programs employed in precision agriculture, in general, should not be lower than $8.6 \mathrm{~m}$. Conversely, exclusively for plant attributes, should not be lower than $10.7 \mathrm{~m}$.

In Figure 1 are shown the maps of kriging bean productivity and chemical attributes of an Acrustox dystroferric in Selvíria (MS, Brazil), under the notillage. Thus, in Figure 1, is the map of kriging bean grain productivity (PGB) which presented the highest values $\left(2,160-2,665 \mathrm{~kg} \mathrm{ha}^{-1}\right)$ located mostly in the central region of the map. On the other hand, in the other regions, this productivity ranged from 1,487-1,992 $\mathrm{kg} \mathrm{ha}^{-1}$, corroborating with the values found by Martins et al. (2009) in which were of 2,595-3,379 $\mathrm{kg} \mathrm{ha}^{-1}$.

In Figure 1 are shown the maps of kriging of phosphorous (P2 and P3) and hydrogen potential (pH1). Thus, spatial similarity observed between the attributes specified in depth. Therefore, the maps of kriging of phosphorous $(\mathrm{P})$ and potential hydrogen $(\mathrm{pH})$, presented their highest values (24.8-26.0 $\mathrm{mg} \mathrm{dm}^{-3}$ and 5.36) in the central regions of maps, respectively.

In Table 3 are presented the parameters of the cross-semivariograms, set between the productivity attribute of beans and an Acrustox dystroferric in Selvíria (MS). In Figure 2 are contained the crosssemivariograms, cross-validations and co-kriging maps between the plant attribute versus chemical soil attribute, getting attestation: $P G B=f(P 2)$, $\mathrm{PGB}=\mathrm{f}(\mathrm{P} 3)$ and $\mathrm{PGB}=\mathrm{f}(\mathrm{pH} 1)$ presented spatial dependence. With regard to the performance of cross-semivariograms (Table 3), the relationship of decreasing them, analyzed by the greatness of the coefficient of determination $\left(\mathrm{r}^{2}\right)$, was as follows: 1$)$ $[\mathrm{PGB}=\mathrm{f}(\mathrm{P} 2)](0.880), 2)[\mathrm{PGB}=\mathrm{f}(\mathrm{pH} 1)(0.821)$ and 3) $[\mathrm{PGB}=\mathrm{f}(\mathrm{P} 3)](0.656)$. 
Table 3. Parameters of simple and cross-semivariograms adjusted for productivity of beans and some chemical attributes of a Typic Acrustox under no-tillage in Selvíria, MS, Brazil.

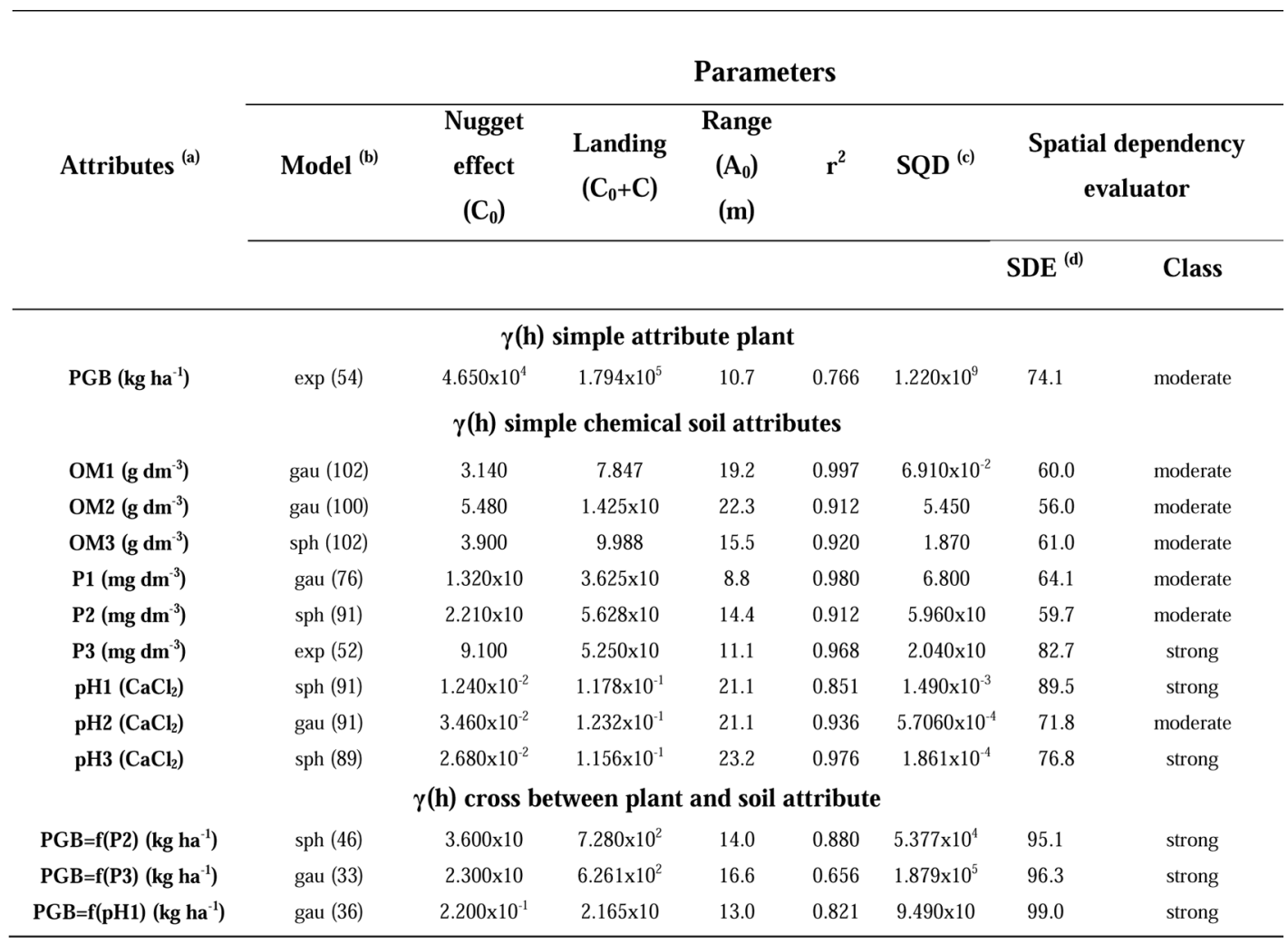

(a) $\mathrm{PGB}=$ productivity of grain of bean, $\mathrm{OM}=$ organic matter, $\mathrm{P}=$ phosphorus, $\mathrm{pH}=$ potential Hydrogen; ${ }^{(b)} \exp =\operatorname{exponential}$, gau = gaussian and $\mathrm{sph}=$ spherical; model succeeded by number in brackets, meaning the number of pairs in the first lag; ${ }^{(c)}$ SQD = sum of squares deviations; ${ }^{(d)} \mathrm{SDE}=$ spatial dependency evaluator. 


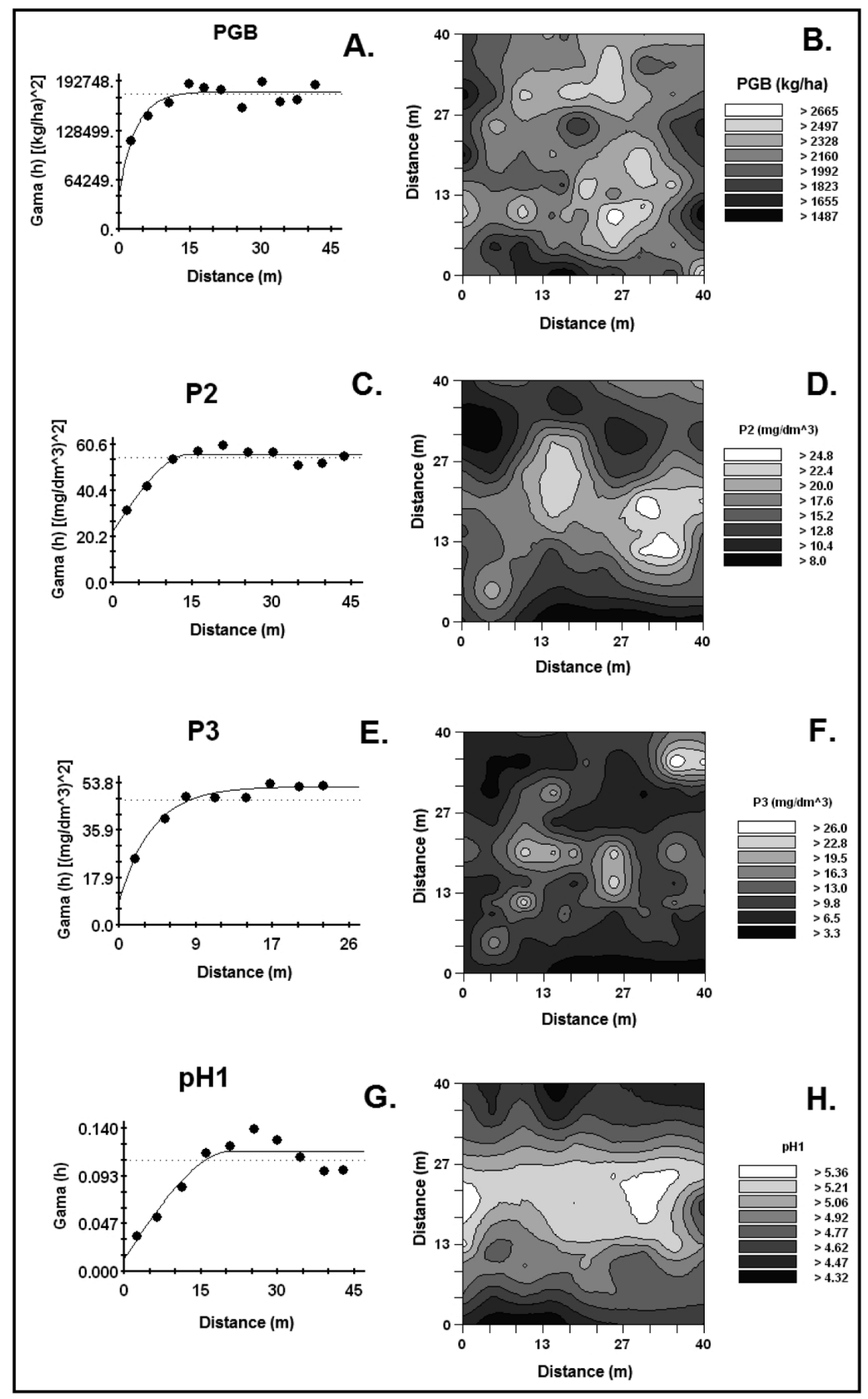

Figure 1. Components geostatistical productivity bean (PGB), phosphorus (P) and the hydrogen potential (pH) of a Typic Acrustox under no-tillage in Selvíria, MS, Brazil. 


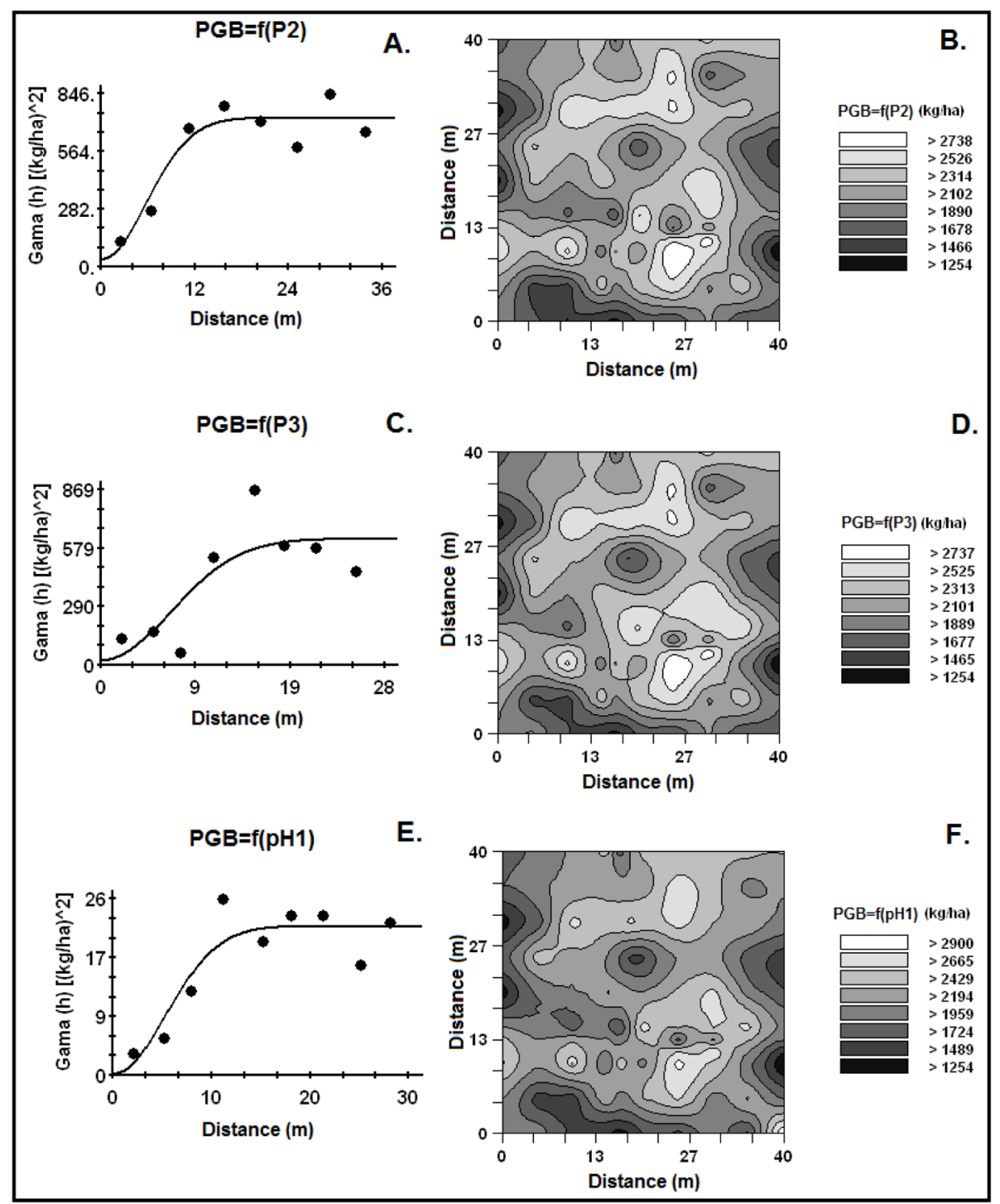

Figure 2. Components geostatistical productivity bean (PGB) as a function of $\mathrm{P} 2, \mathrm{P} 3$ and $\mathrm{pH} 1$ a Typic Acrustox under no-tillage in Selvíria, MS, Brazil. 


\section{Conclusions}

In relation to the spatiality in the no-tillage system, grain productivity of bean could be estimated by means of the co-kriging with the value of $\mathrm{P}$ and the $\mathrm{pH}$ of the soil. Thus, $\mathrm{pH}$ values in the range of 5.05.4 indicated sites with the highest productivity from bean grains, established between 2,160-2,665 $\mathrm{kg} \mathrm{ha}^{-1}$, as well as between $24-26 \mathrm{mg} \mathrm{dm}^{-3} \mathrm{P}$.

\section{References}

Bezerra, C.R.F. 2008. Variabilidade espacial da produtividade de forragem do milho safrinha em função de atributos químicos do solo. Masters Dissertation, State University Paulista (UNESP/ FEIS), Brazil, 70 p.

Buratto, J.S., Cirino, V.M., Scholz, M.B.S., Langame, D.E.M., Fonseca Junior, N.S., Préte, C.E. 2009. Variabilidade genética e efeito do ambiente para o teor de proteína em grãos de feijão. Acta Scintiarum Agronomy. 31, 593-597.

Carneiro, M.A.C., Souza, E.D., Reis, E.F., Pereira, H.S., Azevedo, W.R. 2009. Atributos físicos, químicos e biológicos de solo de Cerrado sob diferentes sistemas de uso e manejo. Revista Brasileira de Ciência do Solo. 33, 147-157.

Carvalho, G.J., Carvalho, M.P., Freddi, O.S., Martins, M.V. 2006. Correlação da produtividade do feijão com a resistência à penetração do solo sob plantio direto. Revista Brasileira de Engenharia Agrícola e Ambiental. 10, 765-771.

Carvalho, L.A., Silva Junior, C.A., Nunes, W.A.G.A, Meurer, I., Souza Junior, W.S. 2011a. Produtividade e viabilidade econômica da cana-de-açúcar em diferentes sistemas de preparo do solo no CentroOeste do Brasil. Revista de Ciências Agrárias. 34, 197-209.
Carvalho, L.A., Meurer, I., Silva Junior, C.A., Cavalieri, K.M.V., Santos, C.F.B. 2011b. Dependência espacial dos atributos físicos de três classes de solos cultivados com cana-de-açúcar sob colheita mecanizada. Revista Brasileira de Engenharia Agrícola e Ambiental. 15, 940-949.

Carvalho, L.A., Meurer, I., Silva Junior, C.A., Centurion, J.F. 2012. Spatial variability of soil physical properties in two management systems in sugarcane crop. Engenharia Agrícola. 32, 60-68.

Coelho, A.M. 2003. Agricultura de precisão: manejo da variabilidade espacial e temporal dos solos e da cultura. In: N. Curi, J.J. Marques, L.R.G. Guilherme, J.M. Lima, A.S. Lopes, V.V.H. Alvarez (Ed.). Tópicos em ciência do solo. Viçosa: Sociedade Brasileira de Ciência do Solo, pp: 249-290.

Companhia Nacional de Abastecimento - CONAB. 2012. Acompanhamento de safra brasileira: grãos, primeiro levantamento, outubro 2012: Feijão terceira safra. Available: $<$ http:// www.conab.gov.br/OlalaCMS/uploads/ arquivos/12_10_09_15_59_18_boletim portugues_outubro_2012.pdf $>$. Accessed: 24 oct.

Corrêa, J.C., Sharma, R.D. 2004. Produtividade do algodoeiro herbáceo em plantio direto no Cerrado com rotação de culturas. Pesquisa Agropecuária Brasileira. 39, 41-46.

Empresa Brasileira de Pesquisa Agropecuária. EMBRAPA. 2006. Sistema brasileiro de classificação de solos. 2ed. Rio de Janeiro: EMBRAPA, 2006. 306 p.

Fageria, N.K., Baligar, V.C. 1996. Response of lowland rice and common bean grown in rotation to soil fertility levels on a varzea soil. Fertilizer Research 45, 13-20.

Fahl, J.I., Camargo, M.B.P., Pizzinato, M.A., Betti, J.A., Melo, A.M.T., DeMaria, I.C., Cangiani, A.M. (Ed.). 1998. Instruções agrícolas para as principais 
culturas econômicas. Boletim 200. 6ed. Campinas: Instituto Agronômico de Campinas, 396 p.

Freddi, O.S. 2003. Variabilidade espacial da produtividade do feijão (Phaseolus vulgaris L.) e atributos químicos de um Latossolo Vermelho Distroférrico de Selvíria (MS) sob preparo convencional e plantio direto. Masters Dissertation, State University Paulista (UNESP/ FEIS), Brazil, 154 p.

Freddi, O.S., Carvalho, M.P., Centurion, J.F., Barbosa, G.F. 2005 Variabilidade espacial da produtividade do feijão em um Latossolo Vermelho distroférrico sob preparo convencional e plantio direto. Acta Scientiarum. Agronomy. 27, 61-67.

GS+: Geostatistics for environmental sciences. 2004. 7ed. Michigan, Plainwell: Gamma Desing Software, $159 \mathrm{p}$.

Kitamura, A.E., Carvalho, M.P., Lima, C.G.R. 2007. Relação entre a variabilidade espacial das frações granulométricas do solo e a produtividade do feijoeiro sob plantio direto. Revista Brasileira de Ciência do Solo. 31, 361-379.

Manzione, R.L. 2002. Variabilidade especial de atributos químicos do solo em Araguari - MG. Masters Dissertation, State University Paulista (UNESP/FCA), Brazil, 155 p.

Martins, M.V. 2007. Aspectos lineares e espaciais da correlação entre a produtividade de feijão (Phaseolus vulgaris L.) com atributos físicos do solo. Monography, State University Paulista (UNESP/FEIS), Brazil, 28 p.

Martins, M.V., Carvalho, M.P., Andreotti, M., Montanari, R. 2009. Correlação linear e espacial entre a produtividade do feijoeiro e atributos físicos de um Latossolo Vermelho distroférrico de Selvíria, Estado de Mato Grosso do Sul. Acta Scientiarum. Agronomy. 31, 147-154.
Megda, M.M., Carvalho, M.P., Vieira, M.X., Andreotti, M., Pereira, E.C. 2008. Correlação linear e espacial entre a produtividade de feijão e a porosidade de um latossolo vermelho de Selvíria (MS). Revista Brasileira de Ciência do Solo. 32, 781-788.

Montanari, R., Carvalho, M.P., Andreotti, M., Dalchiavon, F.C., Lovera, L.H., Honorato, M.A.O. 2010. Aspectos da produtividade do feijão correlacionados com atributos físicos do solo sob elevado nível tecnológico de manejo. Revista Brasileira de Ciência do Solo. 34, 1811-1822.

Montanari, R., Pereira, G.T., Marques Júnior, J., Souza, Z.M., Pazeto, R.J., Camargo, L.A. 2008. Variabilidade espacial de atributos químicos em Latossolo e Argissolos. Ciência Rural. 38, 1266-1272.

Montanari, R., Siqueira, D. S., Marques, J., Pereira, G. T., Pereira, G. T., Souza, G. S. A., Siqueira, G. M. 2012. The use of scaled semivariograms to plan soil sampling in sugarcane fields. Precision Agriculture. 35, 1234-1239.

Novais, R.F., Smyth, T.J. 1999. Fósforo em solo e planta em condições tropicais. Federal University of Viçosa, Viçosa, MG, Brazil, 399 p.

Raij, B. van., Quaggio, J.A., Cantarella, H., Ferreira, M.E., Lopes, A.S., Bataglia, O.C. 1987. Análise química do solo para fins de fertilidade. Campinas: Fundação Cargill, 170 p.

Ramos, S.J., Faquin, V., Rodrigues, C.R., Silva, C.A., Ávila, F.W., Sampaio, R.A. 2010. Utilização de fósforo e produção do feijoeiro: influência de gramíneas forrageiras e fontes de fósforo. Revista Brasileira de Ciência do Solo. 34, 89-96.

Roque, M.W., Matsura, E.E., Souza, Z.M., Bizari, D.R., Souza, A.L. 2008. Correlação linear e espacial entre a resistência do solo ao penetrômetro e a produtividade do feijoeiro irrigado. Revista Brasileira de Ciência do Solo. 32, 1827-1835. 
SSS (Soil Survey Staff). 1998. Keys to soil Taxonomy. USDA. Washington, DC, $326 \mathrm{p}$.

Santos, P.A., Carvalho, M.P., Freddi, O.S., Kitamura, A.E., Freitas, E.E., Vanzela, L.S. 2005. Correlação linear e espacial entre o rendimento de grãos do feijoeiro e a resistência mecânica à penetração em um Latossolo Vermelho distroférrico. Revista Brasileira de Ciência do Solo. 29, 287-295.

Schlotzhaver, S.D., Littell, R.C. 1997. SAS System for elementary statistical analysis. 2ed. Cary, 905 p.

Souza, L.S., Cogo, N.P., Vieira, S.R. 1998. Variabilidade de fósforo, potássio, e matéria orgânica no solo em relação a sistemas de manejo. Revista Brasileira de Ciência do Solo. 22, 77-86.
Trangmar, B.B., Yost, R.S., Uehara, G. 1985. Application of geostatistics to spatial studies of soil properties. Advances in Agronomy. 38, 45-94.

Vieira, C., Paula Júnior, T.J., Borém, A. 2006. Feijão: aspectos gerais e cultura no Estado de Minas. 2ed. Viçosa, MG, Brazil, 600 p.

Weirich Neto, P.H., Sverzut, C.B., Schimandeiro, A. 2005. Necessidade de fertilizante e calcário em área sob sistema plantio direto considerando variabildade esppacial. Revista Brasileira de Engenharia Agrícola e Ambiental. 10, 338-343. 